М.Д. Кушнарева*

Роль религиозного воспитания в судьбе и общественнопросветительской деятельности якутского купца второй гильдии П.И. Кушнарева (конец XIX - начало XX века)

doi:10.31518/2618-9100-2021-1-2

УДК 281.93+241.52(571.5)"18/19"

Выходные данные для цитирования:

Кушнарева М.Д. Роль религиозного воспитания в судьбе и общественно-просветительской деятельности якутского купца второй гильдии П.И. Кушнарева (конец XIX - начало XX века) // Исторический курьер. 2021. № 1 (15). С. 21-30. URL: http://istkurier.ru/data/2021/ISTKURIER-20211-02.pdf
M.D. Kushnareva*

\section{The Role of Religious Education in the Fate, Social and Educational Activities \\ of the Yakutsk Merchant of the Second Guild P.I. Kushnarev \\ (Late $1^{\text {th }}-$ Early $20^{\text {th }}$ Century)}

\author{
doi:10.31518/2618-9100-2021-1-2
}

How to cite:

Kushnareva M.D. The Role of Religious Education in the Fate, Social and Educational Activities of the Yakutsk Merchant of the Second Guild P.I. Kushnarev (Late $19^{\text {th }}-$ Early 20 ${ }^{\text {th }}$ Century) // Historical Courier, 2021, No. 1 (15), pp. 21-30. [Available online:] http://istkurier.ru/ data/2021/ISTKURIER-2021-1-02.pdf

Abstract. The article analyzes the role of the religious education of the Yakutsk merchant of the second guild P.I. Kushnarev in his fate and social and educational activities in the late $19^{\text {th }}$ - early $20^{\text {th }}$ century. It is noted that the problem of the influence of religious education on the fate of representatives of the Siberian merchants is relevant and little studied in modern historiography. The article provides a reconstruction of certain periods of P.I. Kushnarev's life on the basis of his autobiography, preserved in the author's personal archive. The basic principles of P.I. Kushnarev's upbringing in the family of Russian peasants (who were the Old Believers), the chief among which were work, reverence for parents, independence, literacy, knowledge of religious texts, are determined. Part of upbringing was the assimilation of certain stereotypes of behavior associated with the old faith. The article indicates the main results of commercial activities of P.I. Kushnarev related to the wine and fur trade. It was revealed that religious education determined the directions of P.I. Kushnarev's social and educational activities. In 1905 he opened a school, in 1908 the remains of Bishop Methodius were transported. In 1905-1913 prominent figures of the Old Believer church were invited to Pavlovsk. All this contributed to enlightenment, strengthening and maintaining the spirituality of fellow villagers. The religious education of P.I. Kushnarev was reflected in his personal life. He perceived the arrest, nationalization of property and deprivation of civil rights as a test for faith. At present, the legacy left by P.I. Kushnarev retains its significance in the upbringing, enlightenment and spiritual life of the population. The primary school, opened by P.I. Kushnarev in Pavlovsk, celebrated its centenary. The burial place of Bishop Methodius is annually visited by pilgrims, modern adherents of the old faith, from all regions of Russia.

Keywords: North-Eastern Siberia; peasantry; merchants; Old Believers; upbringing; social and educational activities.

The article has been received by the editor on 15.12.2020.

Full text of the article in Russian and references in English are available below.

Аннотация. В статье проанализирована роль религиозного воспитания, полученного якутским купцом 2-й гильдии П.И. Кушнаревым, в его судьбе и общественно-просвети-

\footnotetext{
* Кушнарева Маргарита Дмитриевна, доктор исторических наук, Иркутский государственный университет, Иркутск, Россия, e-mail: rita270880@mail.ru

Kushnareva Margarita Dmitrievna, Doctor of Historical Sciences, Irkutsk State University, Irkutsk, Russia, e-mail: rita270880@mail.ru
} 
тельской деятельности в конце XIX - начале XX в. Отмечено, что проблема влияния религиозного воспитания на судьбу представителей купечества Сибири является актуальной и мало изученной в современной историографии. Представлена реконструкция отдельных периодов жизни П.И. Кушнарева на основе его автобиографии, сохранившейся в личном архиве автора. Определены основные принципы воспитания П.И. Кушнарева в семье русских крестьян-старообрядцев, главными из которых были труд, почитание родителей, самостоятельность, грамотность, знание религиозных текстов. Частью воспитания являлось усвоение определенных стереотипов поведения, связанных со старой верой. В статье указаны основные результаты коммерческой деятельности П.И. Кушнарева, связанные с винной и пушной торговлей. Выявлено, что религиозное воспитание определило направления общественно-просветительской деятельности П.И. Кушнарева. В 1905 г. им была открыта школа, в 1908 г. перевезены останки епископа Мефодия. В 1905-1913 гг. в Павловск были приглашены видные деятели старообрядческой церкви. Все это способствовало просвещению, укреплению и поддержанию духовности односельчан. Религиозное воспитание П.И. Кушнарева отразилось на его личной жизни. Арест, национализацию имущества и лишение гражданских прав он воспринял как испытание за веру. В настоящее время наследие, оставленное П.И. Кушнаревым, сохраняет свое значение в деле воспитания, просвещения и духовной жизни населения. Начальная школа, открытая П.И. Кушнаревым в Павловске, отпраздновала свой столетний юбилей. Место захоронения епископа Мефодия ежегодно посещают паломники, современные приверженцы старой веры, со всех регионов России.

Ключевые слова: Северо-Восточная Сибирь; крестьянство; купечество; старообрядчество; воспитание; общественно-просветительская деятельность.

Проблема роли религиозного воспитания в формировании мировоззрения, судеб и жизнедеятельности представителей сибирского купечества привлекает внимание ученых и широкой общественности. Влияние воспитания, основанного на фундаментальных ценностях старообрядческой веры, на жизнедеятельность крестьян Забайкалья впервые отметил в своих работах Н.М. Ядринцев ${ }^{1}$. Современный исследователь истории старообрядчества Ф.Ф. Болонев писал, что приверженность к старой вере, следование строгой морали в воспитании детей вели к формированию целого слоя авторитетных представителей старообрядчества, чье имя было известно не только в пределах Российской империи ${ }^{2}$. Он же указал на тот факт, что о роли старообрядческой этики и воспитания в процессе формирования личных и деловых качеств выходцев из крестьянского сословия на отдаленных территориях Сибири, в отличие от центральной России, известно очень мало ${ }^{3}$. Проблема взаимосвязи между религиозными ценностями, символами и практикой повседневного хозяйствования в среде предпринимателей-старообрядцев была исследована В.В. Керовым ${ }^{4}$. Анализ хозяйственной этики и воссоздание роли старообрядческого предпринимательства в экономической истории России XVIII-XIX вв. представлены в монографии Д.Е. Раскова ${ }^{5}$. Вклад некоторыХ купцов-старообрядцев в экономическое развитие Сибири, их общественно-просветительская и благотворительная деятельность представлены в «Энциклопедическом словаре по истории купечества и коммерции Сибири» ${ }^{6}$ В современной историографии были также рассмотрены проблемы влияния российского законодательства на развитие религиозной и хозяйственной

\footnotetext{
${ }_{1}^{1}$ Ядринцев Н.М. Раскольничьи общины на границе Китая. Земледелец, дипломат и воин // Сибирский сборник. СПб., 1886. Кн. 1. С. 21-47.

${ }^{2}$ Болонев Ф.Ф. Старообрядцы Алтая и Забайкалья: опыт сравнительной характеристики. Барнаул, 2001. С.4.

${ }^{3}$ Болонев Ф.Ф. Старообрядцы Забайкалья в XVIII-XX вв. Улан-Удэ. 2009. С. 47.

${ }^{4}$ Керов В.В. «Се человек и дело его...»: Конфессионально-этические факторы старообрядческого предпринимательства в России. М., 2004.

${ }^{5}$ Расков Д.Е. Экономические институты старообрядчества. СПб., 2012.

${ }^{6}$ Энциклопедический словарь по истории купечества и коммерции Сибири: в 2 т. Новосибирск, 2012-2013.
} 
деятельности предпринимателей-выходцев из старообрядческой среды северо-восточной Сибири ${ }^{7}$, а также вопросы влияния религиозного воспитания на формирование предпринимательской и общественно-просветительской деятельности регионального купечества на примере якутских купцов 1-й гильдии Акепсима и Петра Кушнаревых ${ }^{8}$. При этом, однако, вопрос о роли религиозного воспитания в становлении личностей отдельных представителей сибирского купечества, которые внесли существенный вклад в развитие духовности населения отдаленных территорий Российской империи, требует дальнейшей разработки. Основной целью данной публикации является исследование влияния религиозного воспитания якутского купца 2-й гильдии П.И. Кушнарева на его судьбу и общественно-просветительскую деятельность, пришедшуюся на конец XIX - начало XX в.

Достижение поставленной цели стало возможным благодаря анализу дневника П.И. Кушнарева, сохранившегося в личном архиве автора. В период с 1897 по 1908 г. Петр Иванович бережно собирал и хранил в дневнике черновики писем епископу Мефодию, его фотографию, делопроизводственные документы канцелярии Иркутского генерал-губернатора о ссылке Мефодия и перезахоронении останков на кладбище в селе Павловск. В 1929 г. дневник пополнился рукописью автобиографии П.И. Кушнарева, которая была предназначена для публикации в газете «Автономная Якутия» с целью восстановления доброго имени и гражданских прав. Рукопись содержит важные и интересные для современной науки сведения, позволяющие реконструировать отдельные эпизоды жизни семей русских крестьян-старообрядцев на отдаленных территориях северо-востока России. Следует отметить, что рукопись выполнена с использованием черных и синих чернил, красивым каллиграфическим почерком. Стиль рукописи и употребляемые в ней словарные обороты напрямую связаны с воспитанием П.И. Кушнарева в русле старообрядческой этики. Это позволяет читателям ощутить дух времени и степень приверженности автора и его окружения старой вере. Завершают дневник письмо П.И. Кушнарева священнику нерюктяйской якутской церкви отцу Афанасию от 1914 г. и фотографии видных деятелей русской старообрядческой церкви начала XX в. с дарственными надписями на оборотах. Страницы дневника не пронумерованы, частично прошиты. Следует отметить, что сведения из автобиографии П.И. Кушнарева, использованные в настоящей публикации, были критически проанализированы автором и подкреплены фактическими данными из делопроизводственных источников Национального архива Республики Саха (Якутия).

Петр Иванович Кушнарев родился в 1863 г. в многодетной семье русских крестьянпереселенцев с Аянского тракта - Ивана Михайловича (1833-1897) и Варвары Тимофеевны (Истифеевой $)^{9}$ Кушнаревых. Кроме него в семье насчитывалось еще пятеро детей: Илларион, Максим, Евстигней, Ирина, Агафья ${ }^{10}$. Детство Петра прошло в доме его отца среди икон и книг ${ }^{11}$ (рис. 1).

\footnotetext{
${ }^{7}$ Дамешек Л.М., Кушнарева М.Д. Становление купечества из старообрядческой среды в северо-восточной Сибири (II половина XIX - начало XX в.) // Вестник Бурятского государственного университета. Сер. «История». 2013. № 7. С. 16-22.

${ }^{8}$ Кушнарева М.Д. Исторический портрет якутского купца 1-й гильдии П.А. Кушнарева // Гуманитарный вектор. 2020. Т. 15. № 3. С. 91-100; Кушнарева М.Д. Исторический портрет якутского купца 1-й гильдии А.М. Кушнарева // Известия Иркутского государственного университета. Сер. «История». 2020. Т. 32. С. 4-10.

${ }^{9}$ Согласно Ведомости Тарбагатайского волостного правления о семьях крестьян-переселенцев на Аянский тракт, фамилия Тимофея Истифеева указана как Естифеев (Государственный архив Республики Бурятия (ГАРБ). Ф. 207. Оп. 1. Д. 159. Л. 243-246).

${ }^{10}$ Национальный архив Республики Саха (Якутия) (НАРС (Я)). Ф. 137. Оп. 1. Д. 24. Л. 21.

${ }^{11}$ После национализации имущества П.И. Кушнарева в 1921 г. в его доме до 1990-х гг. размещался сельский магазин. В настоящее время дом П.И. Кушнарева в пос. Павловск Мегино-Кангаласского улуса Республики Саха (Якутия) сохранился и пустует.
} 


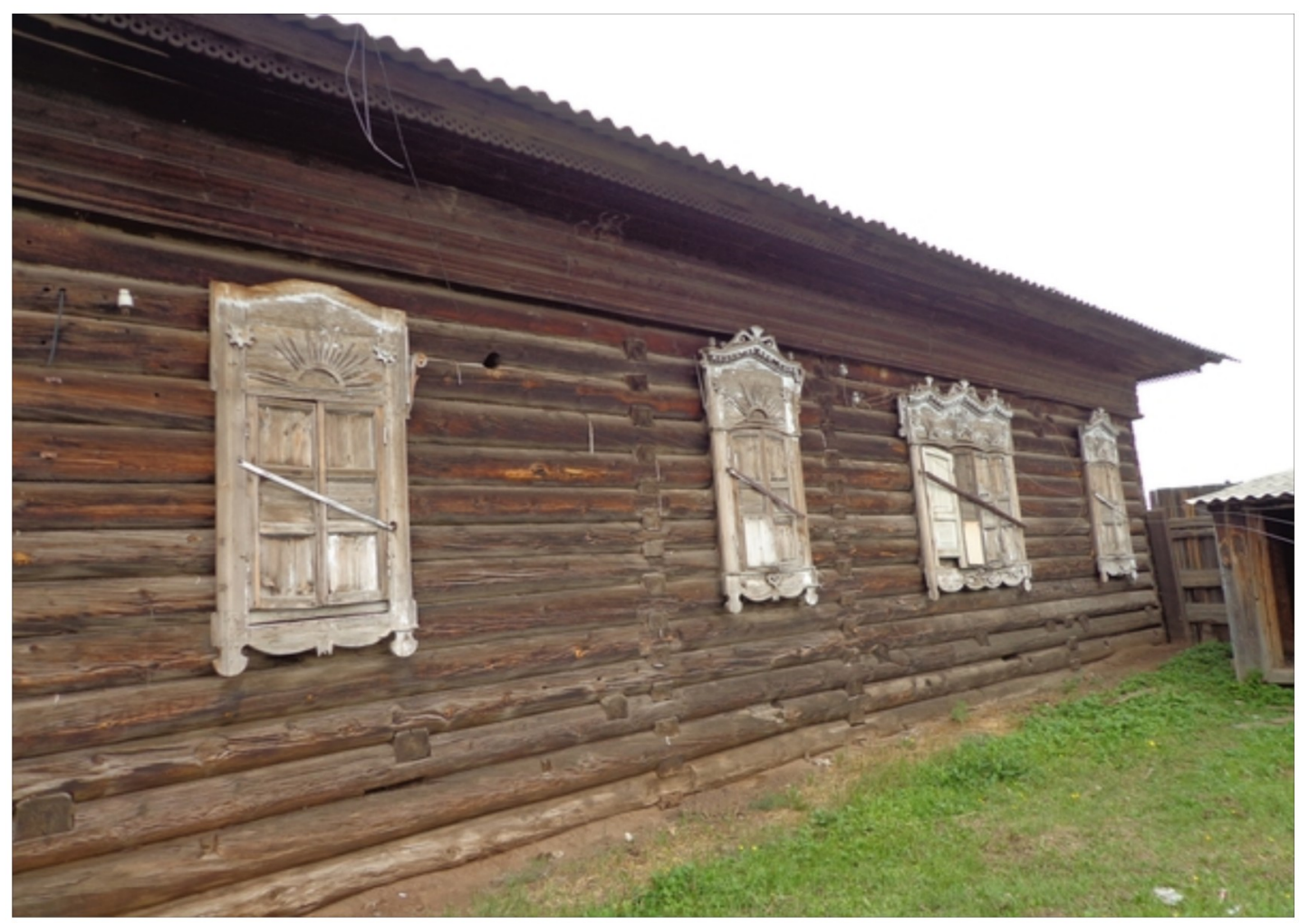

Рис. 1. Дом П.И. Кушнарева в селе Павловск

(фото автора 2018 г.).

В большой религиозной семье на ребенка с самого раннего детства возлагался ряд обязанностей: послушание родителям и почитание их, воспитание себя в страхе Божием, развитие самостоятельности ${ }^{12}$. С ранних лет дети трудились в хозяйстве родителей, выезжали на сенокосы, занимались возделыванием земли под яровые, сбором урожая овощей, уходом за скотом. Сенокосные угодья располагались на заливных островах р. Лены, сено приходилось вывозить верхом на лошадях и лодках, связывая веревками в охапки ${ }^{13}$. Все дети в семье были физически развитыми, выносливыми и крепкими. Кроме сельского хозяйства с ранних лет дети занимались рыболовством, промыслом ягод и грибов, которых заготавливалось за лето большое количество. Труд выступал одним из основных факторов воспитания. Кроме трудовых обязанностей у детей было много разных игр, которые делились на зимние и летние. На воздухе играли в бабки, городки, коршуна, чертика, в войну и партизан. Зимой катались на специально устроенных горках-катушках, играли в снежки, катались на коньках по льду р. Лены. Большинство игр сопровождалось пением и специальными приговорами. Дома у детей было еще одно развлечение - сказки о старине, которые рассказывали их бабушки и дедушки. На всю жизнь Петр Кушнарев запомнил предание своего отца о переселении семей крестьян-старообрядцев из польской Ветки в Сибирь. История о том, как под конвоем шли переселенцы через Тобольск и Верхотурье, как бросали жребий вблизи Иртыша, кому остаться, а кому идти дальше в Сибирь, передавалась из поколения в поколение.

К детям в семье относились очень хорошо, любили их, называли ласковыми словами. Ориентируясь на пример родителей, ребята с ранних лет усваивали определенные стереотипы поведения, связанные со старой верой: уникальность молитвы, особенности крестного

\footnotetext{
${ }^{12}$ Щевьев А.А. Историко-культурные особенности семейного воспитания и образования в общинах старообрядцев (на материалах села Центральной России) // Современные проблемы науки и образования. № 5. С. 8. [Электронный ресурс]. URL: http://www.science-education.ru/ru/article/view?id=14786 (дата обращения: 30.11.2020).

${ }^{13}$ Афанасьев П.А. К вопросу о переселении в Якутскую область. М., 1911. С. 6-7.
} 
знамения и поклонов, строжайшее соблюдение поста. Вся атмосфера семейной жизни староверов способствовала постижению детьми всевозможных бытовых обычаев ${ }^{14}$.

Всем староверам села Павловск, в т.ч. и семье Кушнаревых, был присущ культ чистоты. Это проявлялось в религиозной жизни и в быту, в отношении к пище и к посуде. Для всех старообрядцев общими были запреты в питании. Им, в силу религиозных воззрений, запрещалось принимать в пищу всякое животное с нераздвоенным копытом (конь), парных птиц (голубь, скворец, воробей, лебедь), «давленину», т.е. пойманную силками, тентами и плахами птицу, диких животных (заяц, белка, барсук). Запрещалось оставлять воду не прикрытой. Если посудинка с водой не имела крышки, то ее обязательно закрывали двумя лучинками, положив их крестом ${ }^{15}$. Крестьянам с. Павловск, как и другим старообрядцам всех толков и согласий, запрещалось иметь общение с мирскими («инаковерующими») в питании и заключении браков. Для них имели особую посуду, которую хранили отдельно. Запреты были вызваны, прежде всего, гигиеническими соображениями. В семье порицалось и запрещалось употребление вина, табака.

C 8-9-летнего возраста детей начали обучать грамоте по славянской «Азбуке». Чтению отводилась значительная часть их свободного времени. После уроков грамоты по «Азбуке» дети начинали изучение Законов Божьих, Евангелия, учили молитвы, тексты церковных песен на старославянском языке. Под руководством отца дети осваивали арифметику и каллиграфию, свободно владели якутским языком. Основной целью домашнего образования было основательное, порой дословное знание апологетической литературы, в первую очередь, традиционной дониконовской книжности, свободное цитирование по обсуждаемым вопросам. И это не случайно. Книжное слово являлось высшим авторитетом, а цитата - важнейшим аргументом в любых спорах ${ }^{16}$. Молитвой сопровождалось каждое ежедневное действие членов семьи: пробуждение, прием пищи, отход ко сну. По выходным дети вместе с родителями посещали службы в молитвенном доме Павловска, которые длились по 4-5 часов. Таковы были основные принципы воспитания детей в семье крестьян-старообрядцев Кушнаревых, которые оказали влияние на всю дальнейшую жизнь и деятельность Петра Ивановича.

В 1877 г. в возрасте 14 лет П.И. Кушнарев поступил на службу к своему богатому родственнику - А.М. Кушнареву. С 1877-1881 гг. П.И. Кушнарев вел винную торговлю в Якутске, затем перевозил спирт в питейные заведения Верхоянска ${ }^{17}$. В 1881-1894 гг. занимался «отпуском вина из питейного заведения Верхоянска» ${ }^{18}$. Вот как об этом этапе своей жизни он рассказывает в автобиографии, составленной в 1929 г. для публикации в газете «Автономная Якутия». Приведем небольшую цитату с сохранением стилистики источника. «Родился я в этом Павловском селении на второй год основания его ${ }^{19}$. В 14 лет отдан был, по бедности родителей, своему дяде Акепсиму ${ }^{20}$. Посадили меня в подвал торговать вином. Дело нечистое, греховное, но в те юношеские годы в грехе не понимал. И вот однажды, переливая спирт, облил себе одежду и как-то прикоснулся к огню, одежда на мне загорелась и почти весь обгорел. Пролечился четыре года. Правый бок весь стянуло, кулак

\footnotetext{
${ }^{14}$ Щевьев А.А. Историко-культурные особенности... С. 8.

${ }^{15}$ Болонев Ф.Ф. Старообрядцы Алтая и Забайкалья... С. 29.

${ }^{16}$ Щевьев А.А. Историко-культурные особенности... С. 8

${ }^{17}$ НАРС (Я). Ф. 216. Оп. 2. Д. 1717. Л. 3.

${ }^{18}$ НАРС (Я). Ф. 12. Оп. 1. Д. 23222. Л. 17.

19 Здесь возможна неточность автора автобиографии. По данным старосты крестьян Аянского тракта, в 1870 г. на Аянском тракте проживали семьи русских крестьян-переселенцев, в числе которых была семья Ивана Михайловича Кушнарева с женой и пятью детьми (НАРС (Я). Ф. 137. Оп. 1. Д. 24. Л. 4-7 об.). Согласно ведомости крестьян-переселенцев с Аянского тракта, в села Павловск и Новопокровск Якутского округа Якутской области переселилось 294 человека только в 1871 г. (НАРС (Я). Ф. 137. Оп. 1. Д. 24. Л. 21). Следовательно, местом рождения П.И. Кушнарева является село Усть-Мая (в настоящее время районный центр УстьМайского улуса Республики Саха (Якутия)).

${ }^{20}$ Здесь имеется в виду якутский купец 1-й гильдии Акепсим Михайлович Кушнарев, который приходился дядей П.И. Кушнареву.
} 
плохо сжимался, раны до сих пор не зажили. Однажды сослуживец мой Кулаков Аркадий увидал в бане, испугался меня, выбежал и рассказал, что черт в бане» ${ }^{21}$.

В 1895-1905 гг. П.И. Кушнарев работал приказчиком в торговом отделении А.М. Кушнарева в Булуне. Здесь он занимался разъездной меновой пушной торговлей в северных районах Якутской области. К 1905 г. скопил небольшой капитал и получил свидетельство о принадлежности ко 2-й купеческой гильдии ${ }^{22}$. Однако на пике своей торговой деятельности во время разъездов по северной тундре П.И. Кушнарев попал в пургу. Спасаясь от смерти, он пролежал под снегом двое суток. В возрасте 42 лет П.И. Кушнарев принял решение прекратить торговую деятельность. Возможно, именно тогда, находясь на грани жизни и смерти, П.И. Кушнарев осознал «греховность» своего занятия, после чего вернулся в Павловск и занялся просвещением и духовной жизнью односельчан.

Религиозное воспитание оказало непосредственное влияние на направленность образовательной деятельности П.И. Кушнарева. Распространению религиозного просвещения способствовало принятие указа Комитета министров «Об укреплении начал веротерпимости» от 17 апреля $1905 \Gamma^{23}$ На основании данного указа разрешалось устройство старообрядческих кладбищ, молельных сходок и избрание духовных лиц-наставников. Старообрядцы официально перестали называться «раскольниками», им было разрешено поступать в гимназии, университеты, военные школы. Была провозглашена свобода богослужения и преподавания в духовных школах на родном языке.

В 1905 г. в с. Павловск П.И. Кушнаревым на собственные средства была открыта школа. Основной целью ее создания явилось распространение начального образования среди местного населения. При этом школу могли посещать дети не только из семей крестьян-старообрядцев, но дети «инаковерующих» и «инородцев» из ближайших наслегов. На средства Петра Ивановича учителя приглашались из Москвы, Иркутска, Якутска. В школе для детей уже было все готовое: книги, бумага, перья. Основное внимание в образовании отводилось каллиграфии, арифметике, грамоте, чтению. Преподавались Законы Божьи и древнецерковное пение. Открытие школы П.И. Кушнарев описал в своей автобиографии: «Какие средства были, на них соорудил училище, повесил вывеску, на которой и теперь написано “Старообрядческое училище”. На свой счет нанимал учителей, тогда ссыльных политических, в числе коих был Чистов. Жена экспедитора Чистова, который сейчас находится в Якутске, выписывала из Москвы и России учителей и, не доверяясь учителям, сам учил пять годов. Не осталось ни одного дома, начиная с Ипатовой избы, кончая Малан[ь]иной и все научились читать, писать и считать. Некоторые вышли учителями и учительницами. Большему научить я не мог, потому что сам учился по славянской азбуке с буквы “аз” и “веди”, да “ангел”, “ангельский”, “архангел”, “архангельский”, “буки”, “Бог”, “Божество”, “Богородица” и так далее. Учение и открытие училища мне безнаказанно не прошло, в одно несчастное время приехал Губернатор Крафт ${ }^{24}$ с исправником Ходолевичем, арестовали меня в этом училище и посадили на скамью подсудимых. ${ }^{25}$ Мировой суд, где судили, оштрафовал на 10 руб. ${ }^{26}$ Я молчал, не оправдывался, только под конец всплакнул. Деньги взыскали, а чтобы очистить свою совесть, выдали мне свидетельство на право учителя. Вышло вроде того, как Петр Великий неправильно повесил пращура или прадеда поэта Пушкина и, узнав свою ошибку, собственноручно похоронил повешенного мертвеца. Однажды зашла в училище старая купчиха Екатерина Кушнарева ${ }^{27}$ и сказала пророческие

\footnotetext{
${ }^{21}$ Автобиография П.И. Кушнарева (29 июня 1929 г., с. Павловск). - Рукопись // Личный архив автора.

${ }^{22}$ НАРС (Я). Ф. 12. Оп. 1. Д. 23222. Л. 3.

${ }^{23}$ ПСЗ РИ. Собр. 3-е. СПб., 1908. Т. XXV: 1905 г. Отд. 1. Ст. 26125. С. 257-258.

${ }^{24}$ Имеется в виду губернатор Якутской области И.И. Крафт (1907-1913 гг.).

${ }^{25}$ Данные автобиографии П.И. Кушнарева подтверждаются сведениями из «Акта по обвинению П.И. Кушнарева о самовольном открытии старообрядческой школы» (НАРС (Я). Ф. 218. Оп. 1. Т. 2. Д. 2311. Л. 3-7).

${ }^{26}$ Приговор Мирового суда был вынесен на основании ст. 1049 «Уложения о наказаниях уголовных и исправительныХ» 1845 г. (НАРС (Я). Ф. 218. Оп. 1. Т. 2. Д. 2312. Л. 9).

${ }^{27}$ Имеется в виду Екатерина Матвеевна Кушнарева (Борисова) - супруга якутского купца 1-й гильдии А.М. Кушнарева.
} 
слова: “Ты научишь их, они тебя запрут в тюрьму!” Я нашелся и сказал: “Пускай и распнут, а учить буду!”»" ${ }^{28}$ Основание школы в селе Павловск стало значимым событием в жизни местного населения. В 2005 г. школа, основанная П.И. Кушнаревым в 1905 г., отпраздновала свой 100-летний юбилей.

Население старообрядческой общины с. Павловск в конце XIX - начале XX в. остро нуждалось в поддержании духовности, религиозном наставничестве. Религиозное воспитание, знание церковных обрядов позволило П.И. Кушнареву стать сподвижником известного в старообрядческой среде Сибири епископа Мефодия, который в 1895 г. проводил религиозные службы в с. Куйтун Верхнеудинского округа Забайкальской области, где на тот момент существовала крупнейшая в Забайкалье старообрядческая община ${ }^{29}$. Переписка П.И. Кушнарева с епископом Мефодием позволяла поддерживать духовный настрой членов старообрядческой общины Павловска. Осенью 1895 г. Мефодий был арестован в Иркутске, заключен в тюрьму и обвинен в распространении «раскола». В 1897 г. вместе с партией арестантов Епископ Мефодий был сослан в Якутск для поселения в селе Амга. Но уже в Якутске местом его водворения было назначено село Усть-Майское. В это время Мефодий подает прошение Якутскому губернатору В.Н. Скрипицину, в котором он указывает на преклонный возраст, болезни и просит поселить его в старообрядческом селении Павловск среди его единоверцев. Однако в этом ему было отказано, и новым местом ссылки был назначен Вилюйск. О направлении Мефодия на поселение в Павловск ходатайствовал П.И. Кушнарев. Сохранилась записка П.А. Квасникова, заседателя Вилюйского округа, переданная им П.И. Кушнареву, в которой описывались последние месяцы жизни епископа Мефодия в Вилюйске $^{30}$. Смерть Мефодия в 1898 г. была воспринята членами старообрядческой общины Павловска как смерть за веру. В 1908 г. П.И. Кушнарев подал прошение Якутскому губернатору И.И. Крафту о разрешении перевезти тело почившего старообрядческого епископа Мефодия в село Павловск. В том же году прах епископа на пароходе «Громов» из Вилюйска прибыл в село Павловск Якутского округа Якутской области и был перезахоронен на старообрядческом кладбище (рис. 2).

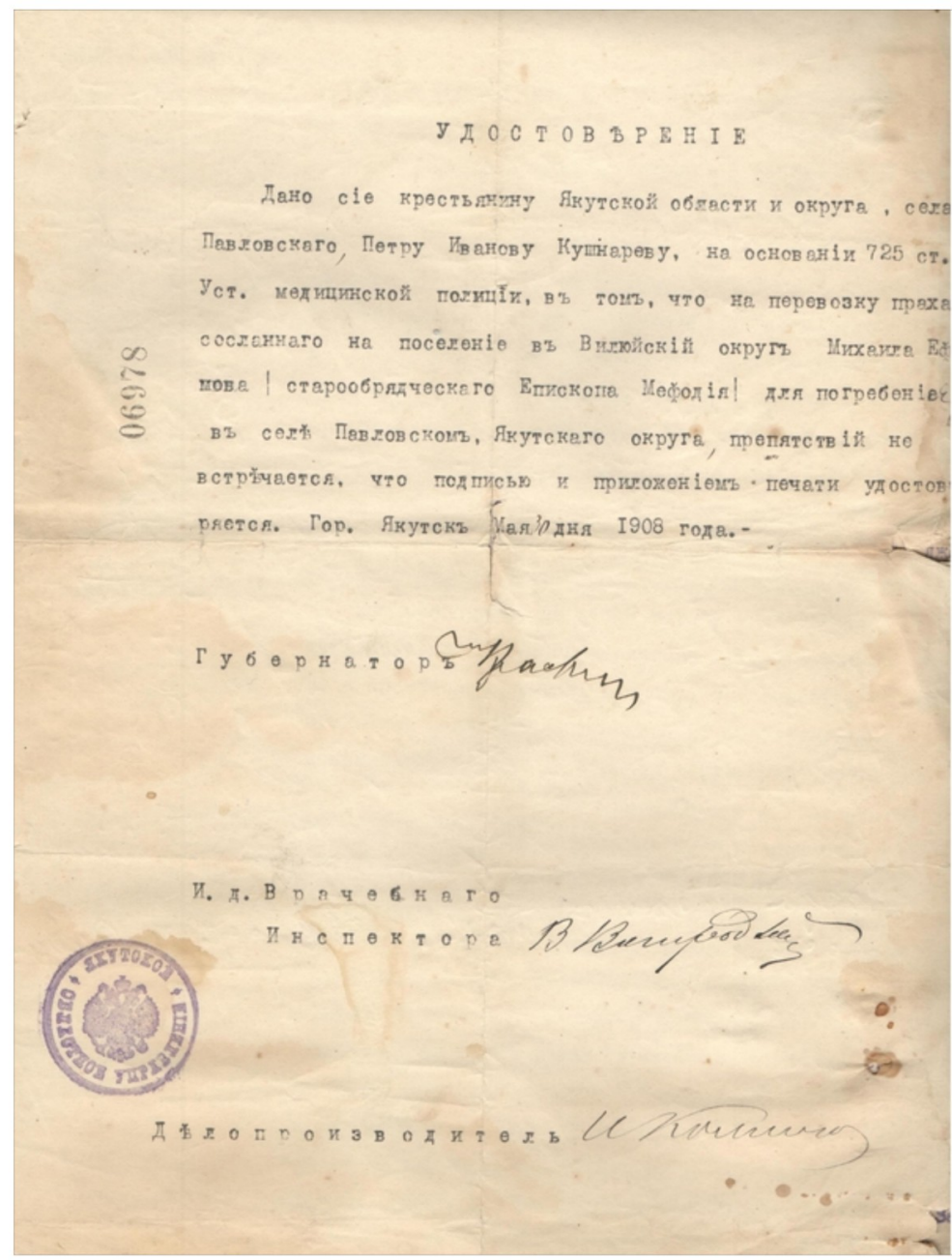

Рис. 2. Удостоверение, выданное П.И. Кушнареву на перевозку и погребение останков епископа Мефодия в Павловске (личный архив автора).

\footnotetext{
${ }^{28}$ Автобиография П.И. Кушнарева...

${ }^{29}$ В миру Михаил Екимов (1824-1898), родился в дер. Выдриха Бийского округа Томской губернии, служил в Перми, упоминается также как епископ Томский. В его ведение входили все сибирские губернии, в т.ч. Забайкальская область.

${ }^{30}$ Кушнарева М.Д. Торговый дом «Наследники А.М. Кушнарева»: происхождение, пушная торговля и общественно-просветительская деятельность во второй половине XIX - начале XX в. Иркутск, 2014. С. 118-121.
} 
Дальнейшее укрепление духовности односельчан П.И. Кушнарев продолжил в статусе старосты крестьянской старообрядческой общины и председателя селения. В Павловске побывали такие видные деятели русской старообрядческой церкви, как епископ Пермский Антоний (1905 г.), Владыка Иосиф - архиерей Восточной Сибири (1913 г.) и другие. Перезахоронение останков епископа Мефодия на старообрядческом кладбище Павловска стало значимым событием для всех верующих не только Якутии конца XIX - начала XX в., но и для современных приверженцев старой веры. В 2003 г. Владыка Мефодий был канонизирован Русской православной старообрядческой церковью как местночтимый святой в лике исповедников.

Воспитание П.И. Кушнарева в духе воззрений старой веры оказало влияние и на его личную жизнь. Наставление родителей «искать жену по вере» было выполнено им неукоснительно. В 1881 г. в возрасте 18 лет он женился на Прасковье Щепуновой - дочери крестьян-переселенцев с Аянского тракта Николая и Степаниды Щепуновых, проживавших в Павловске ${ }^{31}$. Прасковья Николаевна воспитывалась в соответствии со всеми канонами русской старообрядческой церкви, была трудолюбивой, хозяйственной, грамотной. В семье Петра Ивановича и Прасковьи Николаевны Кушнаревых родилось восемь детей, пятеро из которых умерли в младенчестве от эпидемии оспы.

Вся строгость религиозной жизни русских крестьян-старообрядцев отразилась на характере и мировоззрении П.И. Кушнарева, который воспринял вынесенный ему в 1921 г. приговор коллегии Якутского ГубЧК о тюремном заключении, национализации имущества и лишении гражданских прав как испытание веры ${ }^{32}$. Об этом он написал в своей автобиографии следующие слова: «...покалеченный, обнищалый, дряхлый, но от младенческих ногтей с закаленной христианской душой, голод, ссылка, тюрьма, смерть какая бы то ни была, меня не страшат. Страдали наши предки, укрепит и нас к тому Бог, потому, сколько не живи, перейти в загробный мир неминуемо, хотя желаю умереть естественной смертью. Если найдутся среди общества с голосом добрый человек, прошу поместить мое объявление в якутской газете, надеюсь, он незабвен будет у Вседержителя. Во всем, кроме религии, покорный советской власти. Счастлив тот, кто еще не родился и не существовал. Кто не видел под солнцем худых дел человеческих. Я-то ведь пережил много худого и много страдал. Людскую злобу и зависть я узнал» ${ }^{33}$.

Скончался П.И. Кушнарев в 1934 г. на 71 году жизни. Похоронен на старообрядческом кладбище в с. Павловск рядом с могилами своих предков, которые благодаря упорному труду осваивали отдаленные территории северо-восточной Сибири, развивали сельское хозяйство в условиях вечной мерзлоты, воспитывали детей на основе духовности и старообрядческой веры. До сих пор наследие, оставленное П.И. Кушнаревым, сохраняет свое значение в деле просвещения и духовной жизни населения. В краеведческом музее Павловска сохранилось Евангелие в позолоченном окладе, принадлежавшее П.И. Кушнареву. Действует школа, а место захоронения епископа Мефодия ежегодно посещают паломники со всех регионов России.

\section{Лumepamypa}

Афанасьев П.А. К вопросу о переселении в Якутскую область / изд. М.В. Пихтина. М.: Изд-во Т-во скоропеч. А.А. Левенсон, 1911. 19 с.

Болонев Ф.Ф. Старообрядцы Алтая и Забайкалья: опыт сравнительной характеристики. Изд. 2-е, исправленное. Барнаул: Изд-во БЮИ, 2001. 51 с.

\footnotetext{
${ }^{31}$ НАРС (Я). Ф. 137. Оп. 1. Д. 24. Л. 4-7 об.

32 П.И. Кушнарев был арестован 25 марта 1921 г. Коллегия Якутского ГубЧК в апреле 1921 г. обвинила его в сокрытии хлеба и других вещей от учета. Как «враг Советской власти» получил приговор - 1 год лишения свободы. Реабилитирован 25 января 2000 г. // Книга памяти: книга-мемориал о реабилитированных жертвах политических репрессий 1920-1950-х годов / под ред. К.К. Корякина, М.П. Габышева, И.М. Дегтярева, К.Е. Павлова. Якутск, 2002. Т. 1. С. 96.

${ }^{33}$ Автобиография П.И. Кушнарева...
} 
Болонев Ф.Ф. Старообрядцы Забайкалья в XVIII-XX вв. Улан-Удэ: Изд-во БНЦ СО РАН, 2009. 224 с.

Дамешек Л.М., Кушнарева М.Д. Становление купечества из старообрядческой среды в северо-восточной Сибири (II половина XIX - начало XX в.) // Вестник Бурятского государственного университета. Сер. «История». 2013. № 7. С. 16-22.

Керов B.B. «Се человек и дело его...»: Конфессионально-этические факторы старообрядческого предпринимательства в России. М.: Экон-Информ, 2004. 654 с.

Книга памяти: книга-мемориал о реабилитированных жертвах политических репрессий 1920-1950-х годов / под ред. К.К. Корякина, М.П. Габышева, И.М. Дегтярева, К.Е. Павлова. Якутск: Сахаполиграфиздат, 2002. Т. 1. 296 с.

Кушнарева М.Д. Торговый дом «Наследники А.М. Кушнарева»: происхождение, пушная торговля и общественно-просветительская деятельность во второй половине XIX - начале ХХ в. Иркутск: Изд-во Иркут. гос. ун-та, 2014. 247 с.

Кушнарева М.Д. Исторический портрет якутского купца 1-й гильдии А.М. Кушнарева // Известия Иркутского государственного университета. Сер. «История». 2020. Т. 32. С. 4-10.

Кушнарева М.Д. Исторический портрет якутского купца 1-й гильдии П.А. Кушнарева // Гуманитарный вектор. 2020. Т. 15. № 3. С. 91-100.

Расков Д.Е. Экономические институты старообрядчества. СПб.: Изд-во СПбГУ, 2012. $344 \mathrm{c}$.

Щевьев А.А. Историко-культурные особенности семейного воспитания и образования в общинах старообрядцев (на материалах села центральной России) // Современные проблемы науки и образования. 2014. № 5. [Электронный ресурс]. URL: http://www.scienceeducation.ru/ru/article/view?id=14786 (дата обращения: 30.11.2020).

Энциклопедический словарь по истории купечества и коммерции Сибири: в 2 т. Новосибирск: Гео, 2012. Т. 1. 450 с.

Энциклопедический словарь по истории купечества и коммерции Сибири: в 2 т. Новосибирск: Гео, 2013. Т. 2. 464 с.

Ядринцев H.M. Раскольничьи общины на границе Китая. Земледелец, дипломат и воин // Сибирский сборник. Научно-литературное периодическое издание. СПб., 1886. Кн. 1. С. 21-47.

\section{References}

Afanas'ev, P.A. (1911). K voprosu o pereselenii v Yakutskuyu oblast' [On the Issue of Resettlement to the Yakutsk Region], Moscow, Levenson. 19 p.

Bolonev, F.F. (2001). Staroobryadtsy Altaya i Zabaykal'ya: opyt sravnitel'noy kharakteristiki [Old Believers of Altai and Transbaikalia: Comparative Characteristics' Experience]. Barnaul, BYuI. 51 p.

Bolonev, F.F. (2009). Staroobryadtsy Zabaikal'ya v XVIII-XX vv. [Old Believers of Transbaikalia in the $18^{\text {th }}-20^{\text {th }}$ Centuries]. Ulan-Ude, BNTs SO RAN. 224 p.

Dameshek, L.M., Kushnareva, M.D. (2013). Stanovlenie kupechestva iz staroobryadcheskoy sredy v severo-vostochnoy Sibiri (vtoraya polovina XIX - nachalo XX v.). [The Emergence of Merchants from the Old Believers' Circle in North-Eastern Siberia (Second Half of the $19^{\text {th }}$ - Early $20^{\text {th }}$ Centuries)]. In Vestnik Buryatskogo Gosudarstvennogo Universiteta. Seriya: “Istoriya”. No. 7, pp. 16-22.

Entsiklopedicheskiy slovar' po istorii kupechestva i kommertsii Sibiri: $v 2 t$. [Encyclopedia of the History of Merchants and Commerce of Siberia: in 2 vols.]. Novosibirsk, Geo. Vol. 1. 450 p.

Entsiklopedicheskiy slovar' po istorii kupechestva i kommertsii Sibiri: $v 2 t$. [Encyclopedia of the History of Merchants and Commerce of Siberia: in 2 vols.], Novosibirsk, Geo. Vol. 2. 464 p.

Kerov, V.V. (2004). "Se chelovek i delo ego...": Konfessional'no-eticheskiye faktory staroobryadcheskogo predprinimatel'stva v Rossii ["Behold a Man and His Work...": Confessional and Ethical Factors of Old Believer Entrepreneurship in Russia]. Moscow, Ekon-Inform. 654 p.

Koryakin, K.K., Gabyshev, M.P., Degtyarev, I.M., Pavlov, K.E. (Eds.) (2002). Kniga pamyati: kniga-memorial o reabilitirovannykh zhertvakh politicheskikh repressiy 1920-1950-kh godov 
[Book of Memory: a Book-Memorial about the Rehabilitated Victims of Political Repressions in the 1920s-1950s]. Yakutsk, Sakhapoligrafizdat, Vol. 1. 296 p.

Kushnareva, M.D. (2014). Torgovyy dom "Nasledniki A.M. Kushnareva": proiskhozhdenie, pushnaya torgovlya i obshchestvenno-prosvetitel'skaya deyatel'nost' vo vtoroy polovine XIX nachale $X X$ v. [Trading House "Heirs A.M. Kushnareva": the Origin, Fur Trade and Public Activity in the Second Half of the $19^{\text {th }}-$ Early $20^{\text {th }}$ Century]. Irkutsk, IGU. 247 p.

Kushnareva, M.D. (2020). Istoricheskiy portret yakutskogo kuptsa pervoy gil'dii P.A. Kushnareva [Historical Portrait of the Yakutsk Merchant of the 1st guild P.A. Kushnarev]. In Gumanitarnyiy vektor. Vol. 15. No. 3, pp. 91-100.

Kushnareva, M.D. (2020). Istoricheskiy portret yakutskogo kuptsa pervoy gil'dii A.M. Kushnareva [Historical Portrait of the Yakutsk Merchant of the 1st guild A.M. Kushnarev]. In Izvestiya Irkutskogo gosudarstvennogo universiteta. Seriya “Istoriya”. Vol. 32, pp. 4-10.

Raskov, D.E. (2012). Ekonomicheskiye instituty staroobryadchestva [Economic Institutions of the Old Believers]. St Petersburg, SPbGU. 344 p.

Shchev'ev, A.A. (2014). Istoriko-kul'turnyye osobennosti semeynogo vospitaniya i obrazovaniya v obshchinakh staroobryadtsev (na materialakh sela tsentral'noy Rossii) [Historical and Cultural Features of Family Upbringing and Education in the Communities of Old Believers (Based on Materials from Villages of Central Russia)]. In Sovremennyye problemy nauki i obrazovaniya. No. 5. Available at: URL: http://www.science-education.ru/ru/article/view?id=14786 (date of access: 30.11.2020).

Yadrintsev, N.M. (1886). Raskol'nich'i obshchiny na granitse Kitaya. Zemledelets, diplomat i voin [Schismatic Communities on the Border of China. Farmer, Diplomat and Warrior]. In Sibirskiy sbornik. Nauchno-literaturnoye periodicheskoye izdanie. St. Petersburg, B. 1, pp. 21-47.

Статья поступила в редакцию 15.12.2020 2. 